\title{
Prevalence, seroconversion and mother-to- child transmission of dual and triplex infections of HIV, hepatitis B and C viruses among pregnant women in Nigeria: study protocol
}

George Uchenna Eleje ${ }^{1,2^{*}}$, Ikechukwu Innocent Mbachu ${ }^{1,2}$ (D) Uchenna Chukwunonso Ogwaluonye ${ }^{3} \mathbb{D}$, Stephen Okoroafor Kalu ${ }^{4} \mathbb{D}$, Chinyere Ukamaka Onubogu ${ }^{5} \mathbb{D}$, Sussan Ifeyinwa Nweje ${ }^{6}$, Chinwe Elizabeth Uzochukwu ${ }^{7}$ (D) Chike Henry Nwankwo ${ }^{8}$ (D), Preye Owen Fiebai ${ }^{9,10}$ (D), Olabisi Morebise Loto $^{11,12}$ (D), Godwin Otuodichinma Akaba ${ }^{13,14}$ (D), Hadiza Abdullahi Usman ${ }^{15,16}$ (D), Ayyuba Rabiu ${ }^{17,18}$ (D), Richard Obinwanne Egeonu ${ }^{2}$ (D), Odion Emmanuel Igue ${ }^{19}$ (D), Bukola Abimbola Adesoji ${ }^{20}$ (D), Chiamaka Henrietta Jibuaku ${ }^{3}$, Prince Ogbonnia Aja $^{21}$ (D), Chiamaka Perpetua Chidozie ${ }^{21}$ (D), Hadiza Sani Ibrahim ${ }^{18}$ (D) Fatima Ele Aliyu ${ }^{18}$ (D) Aisha Ismaila Numan ${ }^{16}$ (D), Ogbonna Dennis Okoro ${ }^{22}$ (D), Solace Amechi Omoruyi ${ }^{10}$ (D) ljeoma Chioma Oppah ${ }^{10}$ (D) Ubong Inyang Anyang ${ }^{14}$ (D) Aishat Ahmed $^{14}$ (D), Shirley Nneka Chukwurah ${ }^{23}$, Osita Samuel Umeononihu ${ }^{1,2}$ (D), Rebecca Chinyelu Chukwuanukwu ${ }^{21}$ (D), Eric Okechukwu Umeh ${ }^{24}$ (D), Ekene Agatha Emeka ${ }^{25}$ (D) Chukwuanugo Nkemakonam Ogbuagu ${ }^{26}$ (D), Ibrahim Adamu Yakasai ${ }^{17,18}$ (D), Oliver Chukwujekwu Ezechi ${ }^{27}$ (D) Joseph Ifeanyichukwu Ikechebelu ${ }^{1,2}$ (D) and Triplex infection in pregnancy collaboration group

\section{Abstract}

Background: Nigeria contributes significantly to the global burden of HIV, Hepatitis B and C infections, either singly or in combinations, despite progress in HIV care regionally and globally. Although some limited data on mono infection of HIV, Hepatitis B and C virus infections do exists, that of dual and triplex infections, including seroconversion and mother-to-child transmission (MTCT) rates necessary for planning to address the scourge of infections in pregnancy are not available.

Objectives: To determine the seroprevalence, rate of new infections, MTCT of dual and triple infections of HIV, Hepatitis B and C viruses and associated factors, among pregnant women in Nigeria.

(Continued on next page)

\footnotetext{
* Correspondence: georgel21@yahoo.com

'Department of Obstetrics and Gynecology, Nnamdi Azikiwe University, Awka, Nigeria

${ }^{2}$ Department of Obstetrics and Gynecology, Nnamdi Azikiwe University Teaching Hospital, PMB 5025, Nnewi, Anambra State, Nigeria

Full list of author information is available at the end of the article
}

(c) The Author(s). 2020 Open Access This article is licensed under a Creative Commons Attribution 4.0 International License, which permits use, sharing, adaptation, distribution and reproduction in any medium or format, as long as you give appropriate credit to the original author(s) and the source, provide a link to the Creative Commons licence, and indicate if changes were made. The images or other third party material in this article are included in the article's Creative Commons licence, unless indicated otherwise in a credit line to the material. If material is not included in the article's Creative Commons licence and your intended use is not permitted by statutory regulation or exceeds the permitted use, you will need to obtain permission directly from the copyright holder. To view a copy of this licence, visit http://creativecommons.org/licenses/by/4.0/. The Creative Commons Public Domain Dedication waiver (http://creativecommons.org/publicdomain/zero/1.0/) applies to the data made available in this article, unless otherwise stated in a credit line to the data. 
(Continued from previous page)

Method: A multicenter prospective cohort study will be conducted in six tertiary health facilities randomly selected from the six geopolitical zones of Nigeria. All eligible pregnant women are to be tested at enrollment after informed consent for HIV, Hepatitis B and C virus infections. While those positive for at least two of the infections in any combination will be enrolled into the study and followed up to 6 weeks post-delivery, those negative for the three infections or positive for only one of the infections at enrolment will be retested at delivery using a rapid diagnostic test. On enrolment into the study relevant information, will be obtained, and laboratory test of CD4 count, liver function test and full blood counts, and prenatal ultrasonography will also be obtained/performed. Management of mother-newborns pairs will be according to appropriate national guidelines. All exposed newborns will be tested for HIV, HBV or HCV infection at birth and 6 weeks using PCR technique. The study data will be documented on the study case record forms. Data will be managed with SPSS for windows version 23. Ethical approval was obtained from National Health Research Ethics Committee (NHREC) (NHREC/01/01/2007-23/01/2020).

Conclusion: Pregnant women with multiple of HIV, HBV and HCV infections are at increased risk of hepatotoxicity, maternal and perinatal morbidity and mortality. Additionally, infected pregnant women transmit the virus to their unborn baby even when asymptomatic. Children born with any of the infection have significantly poorer quality of life and lower five-year survival rate. Unfortunately, the seroconversion and MTCT rates of dual or triplex infections among pregnant women in Nigeria have not been studied making planning for prevention and subsequent elimination of the viruses difficult. The study is expected to fill this knowledge gaps. Nigeria joining the rest of the world to eliminate the triple infection among children rest on the availability of adequate and reliable data generated from appropriately designed, and powered study using representative population sample. The establishment of the three-in-one study of prevalence, rate of new infection, rate and risk factor for MTCT of dual and triple infection of HIV, Hepatitis B and C viruses among pregnant women in Nigeria is urgently needed for policy development and planning for the improvement of the quality of life of mothers and the elimination of childhood triplex infection.

Keywords: Dual infection, HBV, HCV, HIV, Multiple infection, Nigeria, Seroconversion, Triplex infection

\section{Plain English summary}

Nigeria has large share in the number of persons suffering from HIV, Hepatitis B and C virus infections, either as one infection or combination of the infections. The details of the infections when they are seen in combinations during pregnancy including new acquired infections during pregnancy and transfer of the infections from mother to the baby are not available.

The aim of the study is to find out the number of pregnant women carrying the combined infections of HIV, Hepatitis $B$ and $C$ viruses, new infection rates and rate of transfer of the infection from mother to baby in Nigeria.

A multicenter study will be conducted in six tertiary hospitals selected randomly in all the zones of Nigeria. All qualified pregnant women are to be tested at enrollment after informed consent for HIV, Hepatitis B and C virus infections. While those positive for at least two of the infections in any combination will be allowed to participate in the study and followed up to 6 weeks after delivery, those negative for the three infections or positive for only one of the infections at inclusion in the study will be retested at delivery using a rapid diagnostic test. On enrolment into the study, relevant information will be obtained, and laboratory test of CD4 count, liver function test and full blood counts, and ultrasonography will also be done. Management of mother-newborns pairs will be according to appropriate Nigeria guidelines. All newborns whose mothers test positive to any of the three infections will be tested for HIV, HBV or HCV infection at birth and 6 weeks of life. The study data will be documented on the study forms and later analysed. Ethical approval was obtained from National Health Research Ethics Committee.

Pregnant women with multiple of HIV, HBV and HCV infections are at increased risk of hepatotoxicity, maternal and perinatal morbidity and mortality. Additionally, infected pregnant women can transmit the virus to their unborn baby even when asymptomatic. Children born with any of the infections have significantly poorer quality of life and lower five-year survival rate. Unfortunately, studies on turning from negative tests to positive tests for the infections during pregnancy and transfer of the infection from mother to baby of any of the combined infections among pregnant women in Nigeria have not been conducted making planning for prevention and subsequent elimination of the viruses difficult. The study is expected to fill this knowledge gaps. Nigeria joining the rest of the world to eliminate the triple infection among children rest on the availability of adequate and reliable data generated from appropriately designed, and powered study using representative population sample. The establishment of the prevalence, rate of new infection, rate and risk factors for 
transfer of the infection from mother to baby for combined HIV, Hepatitis B and C viruses among pregnant women in Nigeria is urgently needed for policy makers and planning for the improvement of the quality of life of mothers and the elimination of childhood combined infection.

\section{Background}

The dual (any two of Human Immune Deficiency Virus (HIV), Hepatitis B virus (HBV), and Hepatitis C virus $(\mathrm{HCV})$ ) or triplex (combined HIV, HBV, and HCV) infections occur worldwide with the highest prevalence in sub Saharan Africa. In 2019, United State Agency for International Development (USAID) and the Nigeria National Agency for the Control of AIDS (NACA) estimated that there were 1.9 million people living with HIV in Nigeria, giving a National HIV prevalence of $1.4 \%$ among adults of reproductive age group [1].

Similarly, more than 2 billion people worldwide are estimated to have had hepatitis B virus (HBV) infection, with 350-400 million being chronic carriers of the virus [2]. Although, the prevalence varies throughout the world, it is highest in tropical region of the world [3]. It is estimated that $5-15 \%$ of adults in Sub-Saharan Africa are chronically infected with HBV. A national survey in Nigeria in 2016 reported prevalence rate of $12.2 \%$ [4]. $\mathrm{HCV}$ on the other hand affects about $3 \%$ of the world's population; that is, 170 million people globally [5]. In Nigeria, the estimated prevalence of HCV infection varies widely $(0.4-14.7 \%)$ depending on the region and subpopulation being considered [6, 7]. A common denominator among all the reported prevalence in Nigeria is the lack of generalizability as their data is not nationally representative.

Dual or triplex infection of these viruses in a pregnant woman is a common occurrence because of the shared modes of transmission such as blood transfusion, sharing of sharp objects, and unsafe sex [8]. Thus this poses significant challenge to the unborn child because of the propensity to be transmitted vertically. Secondarily, it is an occupational hazard to service providers. When the three infections coexist, which is common, there is an increased risk of maternal complications, vertical and horizontal transmission to newborn, partners and health service providers respectively [9]. In addition, the progression from HIV to AIDS is faster in people triply infected with HBV and HCV, resulting in the swift worsening of immune system that accompanies HBV and HCV infections [10].

In sub-Saharan Africa, HIV, HBV, and HCV infections are endemic especially among the reproductive age group with high fertility rate, making vertical transmission a major cause for concern [11]. Unlike HIV, HBV and $\mathrm{HCV}$ testing is not routinely done during pregnancy in Nigeria and thus most pregnant women with HBV and HCV are undiagnosed and unknown [12]. Vertical transmission of $\mathrm{HBV}$ and $\mathrm{HCV}$ is thus the norm rather than the exception, as no intervention is provided for these women. In addition, the unknown when coinfected with HIV are treated with antiretroviral Lamivudine monotherapy leading to the development of drug resistance with the attendant morbidity, mortality and increased rate of mother-to-child transmission (MTCT) [13]. Despite progress in HIV care globally and regionally, Nigeria contributes significantly to the global burden of these triplex infections. A major cause for concern is that what is known about these infections especially $\mathrm{HBV}$ and $\mathrm{HCV}$ are majorly based on estimates and extrapolations, making national planning and decision to eliminate these infections almost impossible.

The World Health Organisation (WHO) recommends screening of all HIV patients for viral hepatitis, vaccination against $\mathrm{HBV}$ in non-immune individuals and providing anti $\mathrm{HBV}$ therapy in $\mathrm{HIV} / \mathrm{HBV}$ dually or triply infected patients [14]. Adoption of this strategy will reduce MTCT of these viruses to the children of infected mothers. Despite the marginal progress made in the control of HIV, $32 \%$ of the global gap in MTCT is from Nigeria, the contribution made by HBV and HCV where little or nothing have been done is not known and could only be imagined [15].

Children who are perinatally bared to these viruses are at increased risk of early morbidities, which in turn are associated with fetal and neonatal hepatitis, chronic HBV infection, liver cirrhosis and primary liver cell carcinoma $[16,17]$. A quarter of children infected with HBV often die from HBV related chronic liver diseases in adulthood [18]. Correspondingly, chronic HCV infection is associated with increased incidence of preterm delivery, intrauterine growth restriction and vertical transmission [19]. About $20 \%$ of children vertically infected with HCV develop active infection [20]. In addition, following childbirth, most untreated HIV infected children do not live to see their first birthday, with greater rapid deterioration in those coinfected with Hepatitis B and C viruses [21-23].

Elimination of MTCT of HIV and hepatitis B and C virus infections in Nigeria requires the implementation of feasible, culturally acceptable and sustainable interventions and policies that is based on adequate and reliable in-country evidence and data. Unfortunately, a nationally representative data on prevalence of triplex infection, rate of new infection and MTCT rate based on appropriately design and powered study is lacking. This study is designed and powered to bridge this knowledge gap and facilitate national planning and policy development towards the elimination of childhood triplex infection. In addition, this study is in line with Sustainable Development Goal number 3 for the improvement of 
maternal and child health, as well as the WHO strategy on the determination of the prevalence of dual and triplex infection of HIV, HBV and $\mathrm{HCV}$ infections which will serve as the baseline data [11].

\section{Objectives}

This study is designed to establish the baseline data for the prevalence, rate of new infection, rate and risk factor for mother-to-child transmission of dual and triple infection of HIV, Hepatitis B and C viruses among pregnant women in Nigeria necessary for policy development and planning for the improvement of the quality of life of mothers and the elimination of childhood triplex infection.

\section{Specific objectives}

1. To determine the seroprevalence of the dual and triplex infection among pregnant women in Nigeria.

2. To assess the hepatic enzyme status, and patterns among pregnant women with dual/triplex infections.

3. To determine the new infection rate (seroconversion) and risk factors for seroconversion of dual and triplex infections among pregnant women in Nigeria.
4. To determine the rate of, and sociobiological risk factor for mother-to-child transmission of dual/triplex infections using PCR at 6 weeks post-delivery.

\section{Methodology}

Study design

The study will utilize a multicenter prospective cohort design to determine the seroprevalence, new infection rate, the rate and risk factors for mother- to- child transmission of the triplex infection in pregnancy using polymerase chain reaction (PCR) at birth and 6 weeks postdelivery in Nigeria (Fig. 1).

\section{Study population}

The study will be conducted among mother-infant pairs drawn from pregnant women attending antenatal care in randomly selected tertiary centre in each of the six geopolitical zones of Nigeria.

\section{Study sites}

Participants will be recruited from one randomly selected tertiary level facility in each of the five geopolitical zones in Nigeria apart from the south east zone where the lead institution for the TETFund National Research Fund 2019 is situated. The sites randomly selected in addition to the lead Institution Nnamdi Azikiwe University Teaching Hospital, Nnewi [SouthEast] are;

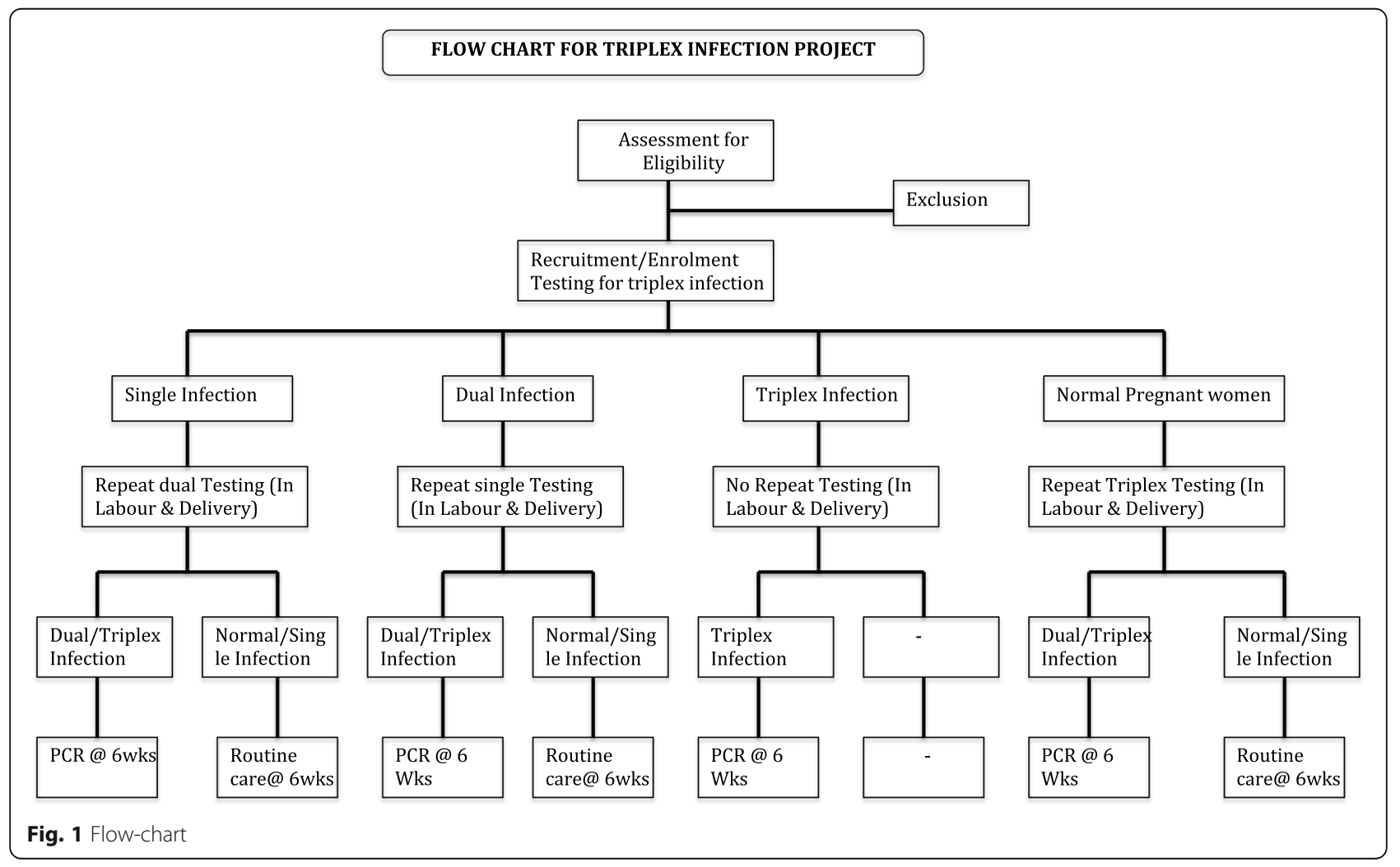


1. University of Maiduguri Teaching Hospital, Maiduguri [North West].

2. Aminu Kano Teaching Hospital, Kano [North East]

3. Obafemi Awolowo University Teaching Hospital Complex, Ile-Ife [South-West]

4. University of Port Harcourt Teaching Hospital, Port Harcourt [South-South]

5. University of Abuja Teaching Hospital, Gwagwalada [North-Central]

\section{Eligibility criteria \\ Inclusion criteria}

All pregnant women receiving antenatal care services at the six randomly selected tertiary hospitals in Nigeria as well as their newborn infants, who did not have any of the exclusion criteria.

\section{Exclusion criteria \\ Mothers}

Women whose pregnancy could not be confirmed by ultrasound or blood pregnancy test.

\section{Newborns}

Infants identified to have gross congenital malformation at birth.

\section{Sample size determination}

The sample size was determined based on the Cochran's formula for sample size determination when the population is more than 10,000 . The sample size was obtained using the Cochran's formula [24] $\mathrm{N}=\mathrm{Z}^{2}$ alphaPQ/d $\mathrm{d}^{2}$, where: $Z=$ standard normal deviation at $95 \%$ confidence interval; $\mathrm{P}=$ prevalence of the problem (prevalence of health facility delivery rate among pregnant women in Nigeria based on a recent study by Adedokun and Uthman that utilized data from 2013 Nigeria Demographic and Health Survey involving 20,192 women who had delivery within 5 years of the survey was put at $38.0 \%$ [25]); $\mathrm{Q}=1-\mathrm{p}$ and $\mathrm{d}=0.05$. The ultimate was adjusted to allow a non-inferiority sample size of 363 obtained and rounded up to 436 to cater for $20 \%$ attrition or nonresponse. Expectedly, at least four hundred and thirty six pregnant women will be recruited from each selected facility.

\section{Sampling technique}

One tertiary hospital was selected from each of the five geopolitical zones in Nigeria by simple random sampling using lottery method apart from the lead institution. In each selected hospital, all consecutive eligible pregnant women who give informed consent will be recruited until sample size is attained.

\section{Study procedure Pregnant mother}

After consenting process, eligible mothers will be privately interviewed at enrollment (during the booking) and at delivery to obtain relevant socio-demographic characteristics, obstetric and medical history. The information will also include address, age, marital status, religion, highest educational attainment, occupation, parity, and gestational age, number of ANC visits, hepatitis B vaccination history, antenatal sexual activity history, anthropometry, as well as HIV, HBV and HCV status, sexual history of the partner, and use of anti-retroviral drugs. All study related information will be entered into Case Record Form (CRF) designed for the study. Gestational age (GA) at enrolment and expected date of delivery will be based on mother's last menstrual period (LMP) or first trimester ultrasound for women with unsure LMP.

The enrollees will be screened for HIV, HBV, and $\mathrm{HCV}$ at enrolment during the booking for ANC using a rapid diagnostic test. Repeat screening will be performed at term or on admission in labor / scheduled delivery for those who screen negative to at least two infections at enrolment. All mothers with at least two infections at enrolment will receive prenatal ultrasonography at 28 to 32 weeks GA to determine fetal wellbeing. Mothers who test positive will be managed according to the national guidelines for the treatment of their infection and prevention of mother-to-child transmission of the infection.

In addition to the routine antenatal follow-up visits for all pregnant women, the participants in the study will in addition be seen at 28-32 weeks and 6 weeks' postpartum. Participants will be reminded of their appointments 2 to 3 days prior to the scheduled visits through a phone call so as to forestall lost to follow-up. The Home-Based Care team will be notified as soon as possible of any defaulting client for tracking. Delivery method will be based on obstetric indication and according to prevailing national guidelines.

\section{Newborn infants}

The infants of participating mothers will be enrolled into the infant arm of the study on delivery and follow-up for 6 weeks. All the infants will benefit from appropriate prophylaxis, vaccination, infant feeding counseling and support, and follow-up. Infants sex, anthropometry (weight, length, occipitofrontal circumference (OFC)) at delivery and follow-up, type of post-exposure prophylaxis received and actual infant feeding practice. The obtained information will also be entered into the CRF. Depending on their exposed status, blood sample will be collected from the infants at birth and 6 weeks for HIV, $\mathrm{HCV}$ and HBV status determination using polymerase chain reaction technique. Results will be communicated 
to the parents after adequate counseling and the affected newborn will be linked for appropriate care and treatment. Neonatal antiretroviral prophylaxis and management will be instituted for all exposed neonates in conjunction with a neonatologist/infectious disease pediatrician according to national guidelines.

\section{Laboratory procedures \\ Maternal HIV, hepatitis $B$ and $C$ virus screening and testing} Ten millimeters of venous blood will be collected in EDTA bottle labeled with participants identifiers by trained phlebotomist, and will be used to carry out the three rapid ELISA tests. Participants who tested negative at baseline will be rescreened for HIV, Hepatitis B and C viruses at delivery or labour. Serial rapid HIV testing will be done according to Nigerian National HIV testing guidelines viz. Alere Determine HIV-1/2 (Alere Medical Co. Ltd., Matsudo, Japan) test kit as a screening test, followed by the Uni-Gold Recombigen ${ }^{\circ} H I V-1 / 2$ (Trinity Biotech, Ireland) assay if positive and finally confirmed by HIV1/2 STAT-PAK (Chembio Diagnostic Systems, Inc., USA). The HBsAg and anti-HCV will be tested using ELISA kit manufactured by LabACON (Hangzhou Biotest Biotech Company, Ltd., China) which has specificity of $99.0 \%$ and a sensitivity of $99.9 \%$ according to company declared figures. The kit has in-built controls. The manufacturer's instruction will be strictly followed. The results will be reported as positive or negative.

\section{HIV, hepatitis $B$ and $C$ viral load determination}

HIV, HBV and HCV viral load will be estimated using ROCHE COBAS CTM/CAP REAL-TIME PCR. All blood specimen for Viral load test and infant status determination will be stored in the minus 25-degree freezer after separation at the sites. The stored samples will be batched transported under cold chain condition for analysis at the Molecular Virology Laboratory at Nnamdi Azikiwe University Teaching Hospital (NAUT H), Nnewi, Anambra State, Nigeria. Fifteen militres of blood will be collected into an EDTA anticoagulant vacutainer tube and gently mixed by inversion. The blood will be centrifuged at $1800 \mathrm{rpm}$ for $25 \mathrm{~min}$. The plasma will be transferred into a $2 \mathrm{ml}$ cryovial tube and stored at - 25 degree centigrade until when enough samples are pooled for testing. Before analysis, frozen specimens will be brought to room temperature until it is completely thawed and vortexed for $10-15 \mathrm{~min}$. The controls will be removed and allowed to equilibrate before use. A vortex mixer will be powered on and set at $56{ }^{\circ} \mathrm{C}$. The $1100 \mu \mathrm{l}$ of the plasma sample will be dispensed into SPU tubes and placed unto the vortex mixer for $10-15 \mathrm{~min}$. The negative, low positive and high positive controls will be pipetted into SPU tubes accordingly.
Workflow The COBAS TaqMan Analyzer 48 or 96 Analyzer will be started within 120 min following completion of specimen and control preparation. The COBAS TaqMan 48 analyzer automatically determines the HBV DNA concentration for the specimens and controls. The DNA concentration will be expressed in copies/mL. The Cycle Threshold value $(\mathrm{Ct})$ for the HBV DNA and the HIV QS DNA will be determined. The HBV DNA concentration based upon the Ct values for the HBV DNA and the HIV-IQS DNA and the lotspecific calibration coefficients provided on the cassette barcodes would also be determined.

Results validation After the COBAS TaqMan 48 analyzer run, the results will be checked for flags or error messages in the result report. Specimens with flags and comments would be interpreted as described in the results section. After accepting, the results would be stored in the data archive. All the used K-tubes would be removed from the COBAS TaqMan 48 Analyzer.

The results would be validated or invalidated depending on whether there is an appearance of a flag or not on any of the controls [HBV L (+) C, v2.0, and CTM (-) C].

\section{Infant HIV, HBV and HCV diagnosis}

Determination of the HIV status of the exposed infant will be done in accordance with current Nigeria National Guideline for PMTCT. All HIV, HBV, HCV exposed infants will be tested using DNA PCR by collecting the dried blood sample (DBS) at birth and age of 6 weeks. The dried blood sample will be analysis centrally using PCR at Molecular Virology Laboratory, NAUTH, Nnewi, Anambra State, Nigeria.

\section{Ethics approval}

Approval was obtained from the National Health $\mathrm{Re}$ search Ethics Committee (NHREC/01/01/2007-23/01/ 2020). The recruiting hospitals also obtained concurrent approvals from their local ethics committees before commencement of the study according to the National Ethics Code. Written informed consent will be obtained from all eligible pregnant women before enrollment into the study.

\section{Pre-testing of study data collection tools}

All the data collection tools will be jointly developed by the study investigators, and sent to obstetrician, pediatrician, biostatistician and infectious diseases expert, and revised to ensure internal validity. Study questionnaire will be pretested through administration to 20 pregnant women in a hospital center other than the center included in the sample. Necessary corrections and adjustments will be carried out based on the feedback 
received. Study data will be collected by trained research assistants under the supervision of the investigators.

\section{Data management plan}

The study's CRFs will be used to collect the study specific information by the research assistants. Information on socio-demographic characteristics, obstetrics and medical history, clinical examination findings, antenatal follow up and laboratory investigation results will be collected. The information on the CRF will be doublyentered into a computer using, cleaned and analysed with Statistical Package for Social Sciences (SPSS) version 23. Univariate analysis will first be conducted to determine the prevalence, rates of new infection, rates and MTCT for HIV, HBV and HCV, followed by bivariate and multiple logistic regression to determine the risk factors for MTCT and new infections. Appropriate statistical test will be used as appropriate. The result outputs will be displayed as tables and figures.

\section{Discussion}

The study is designed to determine the seroprevalence, new infection rate, the rate of and risk factors for mother-to-child transmission (MTCT) of the dual and triplex infection in pregnancy using PCR at 6 weeks post-delivery in Nigeria.

Pregnant women with dual or triplex of HIV, HBV and HCV infections are at increased risk of hepatotoxicity, with attendant higher risk of maternal and perinatal morbidity and mortality. Infected pregnant women can transmit the virus to their unborn baby even when asymptomatic. Children born with any of the infections have significantly poorer quality of life and lower fiveyear survival rate. Unfortunately, the incidence, and MTCT rates of dual or triplex infections among pregnant women in Nigeria is not known making planning for prevention and subsequent elimination of the infections difficult. This study is expected to fill the knowledge gaps.

Nigeria joining the comity of the nations to eliminate the triple infection among children rest on the availability of adequate and reliable data generated from appropriately designed, and powered study using representative population sample. The establishment of the prevalence, rate of new infection, rate of and risk factor for MTCT of dual and triple infection of HIV, Hepatitis B and C viruses among pregnant women in Nigeria is urgently needed for policy development and planning for the improvement of the quality of life of mothers and the elimination of childhood triplex infection.

The study will be conducted in the six geopolitical zones with their distinct cultural, religious and behavior characteristics thus will provide adequate data for policy and planning for the country. However, a possible weakness of the study is that it will be conducted in tertiary institutions, which may make generalization difficult. However, the current weakness in the Nigerian health system have made it possible for women to present first at the Teaching hospital without passing through primary and secondary health facilities. The sociobiological and obstetrics characteristics of pregnant women seen at the teaching hospital in Nigeria are similar to those seen at the secondary and primary facilities [26]. This makes generalization of the results possible for the general population.

A major strength of this study is that is one of the few studies in the country that will be measuring the incidence of HIV, Hepatitis B and C viruses in pregnancy using data from all the six zones of the country. In addition, approval was obtained from the national Ethics community domicile at the Department of Health Planning, Research and Statistics, Federal Ministry of Health, which will make translation to policy easy. Furthermore, almost of all the investigators are members of the Society of Gynecology and Obstetrics of Nigeria (SOGON) will also make translation to Practice Guideline easy.

\section{Abbreviations \\ AIDS: Acquired immunodeficiency syndrome; CRF: Case Record Form; DBS: Dried blood Sample; DNA: Deoxyribonucleic acid; EDTA: Ethylene diamine tetraacetic acid; ELISA: Enzyme Linked Imunosorbent Assay; GA: Gestational age; HBV: Hepatitis B virus; HCV: Hepatitis C virus; HIV: Human Immuno Deficiency Virus; LMP: Last menstrual period; MTCT: Mother-to-child- transmission; NACA: National Agency for the Control of AIDS; NAUTH: Nnamdi Azikiwe University Teaching Hospital; NHREC: National Health Research Ethics Committee; PCR: Polymerase Chain Reaction; PMTC T: Prevention of Mother-to-Child-Transmission; SDG: Sustainable Development Goal; SPSS: Statistical packages of social sciences; USAID: United State Agency for International Development; WHO: World Health Organization}

\section{Acknowledgements}

This project will be supported by Nnamdi Azikiwe University, Awka and Nnamdi Azikiwe University Teaching Hospital, Nnewi, Nigeria. We would like to thank Ngozi Joe-Ikechebelu, Godwin Nchinda, Clara Ajuba, George Chukwuma, and Chide Okocha for their initial participant during the application of the TETFund research grant award.

\section{Authors' contributions}

GU Eleje, II Mbachu, CU Onubogu, UC Ogwaluonye, SO Kalu, RO Egeonu, CE Uzochukwu, CH Nwankwo, SI Nweje, SN Chukwurah, OS Umeononihu, RC Chukwuanukwu, EO Umeh, EA Emeka, CN Ogbuagu and O Ezechi were involved in the overall conceptual design and implementation of the project, and overall revision of the manuscript. A Rabiu, GO Akaba, PO Fiebai, O Loto, HA Usman, C Jibuaku, P Aja, CP Chidozie, HS Ibrahim, FE Aliyu, EO Igue, B Adosoji, AI Numan, OD Okoro, SA Omoruyi, IC Oppah, UI Anyang and A Ahmed were involved in the writing of this manuscript and overall revision. IA Yakasai and II Ikechebelu were involved in revision of the manuscript. The authors read, approved the final manuscript and agree to be accountable for all aspects of the work.

\section{Funding}

The research protocol was funded by the TETFund Research Fund 2019. The views expressed in this publication are those of the author(s) and not necessarily those of the Tertiary Education Trust Fund (TETFund). The funders had no role in the design of the study or writing of the protocol. 


\section{Availability of data and materials}

No data were generated during the current status of the study. Once the study is finalized and the results are published, a specific procedure for obtaining access to the database will be made.

\section{Ethics approval and consent to participate}

An ethical approval was obtained from the National Health Research Ethics Committee (NHREC) with registration number: NHREC/01/01/2007-23/01/ 2020 (approval date: January 23, 2020). In addition, permissions will be obtained from the authorities of the selected tertiary hospitals. An informed consent will be obtained from each study participant prior to the involvement in the study. The collected data will be kept confidential and accessed only by the research team members.

\section{Consent for publication}

Not applicable.

\section{Competing interests}

The authors declare that they have no competing interests.

\section{Author details}

${ }^{1}$ Department of Obstetrics and Gynecology, Nnamdi Azikiwe University, Awka, Nigeria. ${ }^{2}$ Department of Obstetrics and Gynecology, Nnamdi Azikiwe University Teaching Hospital, PMB 5025, Nnewi, Anambra State, Nigeria. ${ }^{3}$ Department of Pharmaceutical Sciences, Nnamdi Azikiwe University, Awka, Nigeria. ${ }^{4}$ HIV Care Laboratory/HIV Care Department, Nnamdi Azikiwe University Teaching Hospital, Nnewi, Nigeria. ${ }^{5}$ Department of Paediatrics, Nnamdi Azikiwe University, Awka, Nigeria. ${ }^{6}$ Department of Nursing, Nnamdi Azikiwe University Teaching Hospital, Nnewi, Nigeria. ${ }^{7}$ Department of Mass Communication, Nnamdi Azikiwe University, Awka, Nigeria. ${ }^{8}$ Department of Statistics, Nnamdi Azikiwe University, Awka, Nigeria. ${ }^{9}$ Department of Obstetrics and Gynecology, University of Port Harcourt, PortHarcourt, Nigeria. ${ }^{10}$ Department of Obstetrics and Gynecology, University of Port Harcourt Teaching Hospital, PortHarcourt, Nigeria. ${ }^{11}$ Department of Obstetrics and Gynecology, Obafemi Awolowo University, Ile Ife, Nigeria. ${ }^{12}$ Department of Obstetrics and Gynecology, Obafemi Awolowo University Teaching Hospital Complex, Ile-Ife, Nigeria. ${ }^{13}$ Department of Obstetrics and Gynecology, University of Abuja, Abuja, Nigeria. ${ }^{14}$ Department of Obstetrics and Gynecology, University of Abuja Teaching Hospital, Abuja, Nigeria. ${ }^{15}$ Department of Obstetrics and Gynecology, University of Maiduguri, Maiduguri, Nigeria. ${ }^{16}$ Department of Obstetrics and Gynecology, University of Maiduguri Teaching Hospital, Maiduguri, Nigeria. ${ }^{17}$ Department of Obstetrics and Gynecology, Bayero University, Kano, Nigeria. ${ }^{18}$ Department of Obstetrics and Gynecology, Aminu Kano Teaching Hospital, Kano, Nigeria.

${ }^{19}$ Department of Physiological Sciences, Obafemi Awolowo University, lle-lfe, Nigeria. ${ }^{20}$ Department of Nursing, Obafemi Awolowo University Teaching Hospital Complex, Ile-Ife, Nigeria. ${ }^{21}$ Immunology Unit, Department of Medical Laboratory Science, Nnamdi Azikiwe University, Awka, Nigeria. ${ }^{22}$ Department of Parasitology \& Entomology, Faculty of Veterinary Medicine, University of Maiduguri Borno State, Maiduguri, Nigeria. ${ }^{23}$ Department of Medicine, Faculty of Medicine, Nnamdi Azikiwe University, Awka, Nigeria. ${ }^{24}$ Department of Radiology, Faculty of Medicine, Nnamdi Azikiwe University, Awka, Nigeria. ${ }^{25}$ Department of Family Medicine, Faculty of Medicine, Nnamdi Azikiwe University, Awka, Nigeria. ${ }^{26}$ Department of Medical Microbiology and Parasitology, Faculty of Medicine, Nnamdi Azikiwe University, Awka, Nigeria.

${ }^{27}$ Nigerian Institute of Medical Research, Lagos, Nigeria.

Received: 4 September 2020 Accepted: 16 September 2020

Published online: 25 September 2020

\section{References}

1. USAID/NACA 2019: Report of Nigerian HIV/AIDS. https://www.unaids.org/en/ resources/presscentre/pressreleaseandstatementarchive/2019/march/201 90314_nigeria.

2. WHO, 2014. Hepatitis B Virus. Available at http://www.who.inf/inf-s/en/fact2 04.html Accessed on August 29, 2019.

3. Geffert K, Maponga TG, Henerico S, Preiser W, Mongella S, Stich A, Kalluvya S, Mueller A, Kasang C. Prevalence of chronic HBV infection in pregnant woman attending antenatal care in a tertiary hospital in Mwanza, Tanzania: a cross-sectional study. BMC Infect Dis. 2020;20(1):395. https://doi.org/10. 1186/s12879-020-05096-2.
4. Olayinka AT, Oyemakinde A, Balogun MS, Ajudua A, Nguku P, Aderinola M, et al. Seroprevalence of hepatitis b infection in Nigeria: a national survey. Am J Trop Med Hyg. 2016;95(4):902-7.

5. Ejeta E, Dabsu R. Prevalence of Hepatitis C Virus and HIV Infection Among Pregnant Women Attending Antenatal Care Clinic in Western Ethiopia. Front Med (Lausanne). 2019;5:366. https://doi.org/10.3389/fmed.2018.00366.

6. Ezechi OC, Lalejaiye OO, Gab-Okafor CV, Oladele DA, Oke BO, Musa ZA. Sero-prevalence and factors associated with hepatitis $B$ and $C$ coinfections in pregnant Nigeria women living with HIV infection. Pan Afr Med J. 2014; 17:197.

7. Opaleye OO, Igboama MC, Ojo JA, Odewale G. Sero-prevalence of HIV, HBV, and HCV and HTLV among pregnant women in southwestern Nigeria. J Immunoassay Immunochem. 2016;37:29-42.

8. Raizada A, Dwivedi S, Bhattacharya S. The hepatitis B, hepatitis C and HIV coinfection at an antiretroviral Centre in Delhi. Trop Dr. 2011;1(3):154-6.

9. Bafa TA, Egata AD. Seroepidemiological patterns and predictors of hepatitis $\mathrm{B}, \mathrm{C}$ and HIV viruses among pregnant women attending antenatal care clinic of Atat hospital Southern Ethiopia. SAGE Open Med. 2020;8: 2050312119900870. https://doi.org/10.1177/2050312119900870.

10. Monje-Agudo P, Castro-Iglesias A, Rivero-Juárez A, Martínez-Marcos F, Ortega-González E, Real LM, et al. Impact of HIV infection on sustained virological response to treatment against hepatitis $C$ virus with pegylated interferon plus ribavirin. Eur J Clin Microbiol Infect Dis. 2015;34(10):1929-36. https://doi.org/10.1007/s10096-015-2434-6.

11. Deressa T, Damtie D, Fonseca K, Gao S, Abate E, Alemu S, et al. The burden of hepatitis B virus (HBV) infection, genotypes and drug resistance mutations in human immunodeficiency virus-positive patients in Northwest Ethiopia. PLoS One. 2017;12(12):e0190149. https://doi.org/10.1371/journal. pone.0190149.

12. Rabiu KA, Akinola Ol, Adewunmi AA, Omololu OM, Ojo TO. Risk factors for hepatitis $B$ virus infection among pregnant women in Lagos Nigeria. Acta Obstet Gynecol Scand. 2010;89(8):1024-8. https://doi.org/10.3109/00016349. 2010.482580.

13. Rusine J, Ondoa P, Asiimwe-Kateera B, Boer KR, Uwimana JM, Mukabayire O, et al. High seroprevalence of HBV and HCV infection in HIV-infected adults in Kigali Rwanda. PLoS One. 2013;8(5):e63303. https://doi.org/10.1371/ journal.pone.0063303.

14. WHO. Regional Committee for the Western Pacific, 068. Triple elimination of mother-to-child transmission of HIV, hepatitis B and syphilis. Manila: WHO Regional Office for the Western Pacific.2017. Available at: https://apps.who. int/iris/handle/10665/260024. Accessed on 18 August 2020.

15. Lemoine M, Thursz MR. Battlefield against hepatitis B infection and HCC in Africa. J Hepatol. 2017;66(3):645-54.

16. Eke AC, Eke UA, Okafor Cl, Ezebielu IU, Ogbuagu C. Prevalence correlates and pattern pf HBV surface antigen in a low resource setting. Virol J. 2011;8: 12. https://doi.org/10.1186/1743-422X-8-12.

17. Wang $\mathrm{CC}$, Cheng PN, Kao JH. Systematic review: chronic viral hepatitis and metabolic derangement. Aliment Pharmacol Ther. 2020;51(2):216-30. https://doi.org/10.1111/apt.15575.

18. Domínguez-Rodríguez S, Prieto L, Fernández McPhee C, Illán-Ramos M, Beceiro J, Escosa $L$, et al. Perinatal HCV transmission rate in HIV/HCV Coinfected women with access to ART in Madrid Spain. PLoS One. 2020; 15(4):e0230109. https://doi.org/10.1371/journal.pone.0230109.

19. Checa Cabot CA, Stoszek SK, Quarleri J, Losso MH, Ivalo S, Peixoto MF, et al. Mother-to-child transmission of hepatitis C virus (HCV) among HIV/HCVCoinfected women. J Pediatric Infect Dis Soc. 2013;2(2):126-35. https://doi. org/10.1093/jpids/pis091.

20. Indolfi G, Easterbrook P, Dusheiko G, El-Sayed MH, Jonas MM, Thorne C, et al. Hepatitis $C$ virus infection in children and adolescents. Lancet Gastroenterol Hepatol. 2019;4(6):477-87. https://doi.org/10.1016/S24681253(19)30046-9.

21. Eleje GU, Edokwe ES, Ikechebelu JI, Onubogu CU, Ugochukwu EF, Okam PC, et al. Mother-to-child transmission of human immunodeficiency virus (HIV) among HIV-infected pregnant women on highly active anti-retroviral therapy with premature rupture of membranes at term. J Matern Fetal Neonatal Med. 2018;31(2):184-90. https://doi.org/10.1080/14767058.2017. 1279600.

22. Eke $A C$, Eleje GU, Eke UA, Xia Y, Liu J. Hepatitis B immunoglobulin during pregnancy for prevention of mother-to-child transmission of hepatitis $B$ virus. Cochrane Database Syst Rev. 2017;2(2):CD008545. https://doi.org/10. 1002/14651858.CD008545.pub2. 
23. Akhtar F, Rehman S. A public health analysis on gaps in disease monitoring and opportunities for improved Care for the Management of hepatitis B and C. Cureus. 2018;10(1):e2077. https://doi.org/10.7759/cureus.2077.

24. Noordzij M, Tripepi G, Dekker FW, Zoccali C, Tanck MW, Jager KJ. Sample size calculations: basic principles and common pitfalls. Nephrol Dial Transplant. 2010;25(5):1388-93.

25. Adedokun ST, Uthman OA. Women who have not utilized health Service for Delivery in Nigeria: who are they and where do they live? BMC Pregnancy Childbirth. 2019;19(1):93. https://doi.org/10.1186/s12884-019-2242-6.

26. Mustapha GU, Ibrahim A, Balogun MS, Umeokonkwo CD, Mamman Al. Seroprevalence of hepatitis B virus among antenatal clinic attendees in Gamawa local government area, Bauchi state Nigeria. BMC Infect Dis. 2020; 20(1):194. https://doi.org/10.1186/s12879-020-4863-9.

\section{Publisher's Note}

Springer Nature remains neutral with regard to jurisdictional claims in published maps and institutional affiliations.

Ready to submit your research? Choose BMC and benefit from:

- fast, convenient online submission

- thorough peer review by experienced researchers in your field

- rapid publication on acceptance

- support for research data, including large and complex data types

- gold Open Access which fosters wider collaboration and increased citations

- maximum visibility for your research: over $100 \mathrm{M}$ website views per year

At $\mathrm{BMC}$, research is always in progress.

Learn more biomedcentral.com/submissions 